\title{
Breast-milk production in Australian women
}

\author{
By S. RATTIGAN, ANN V. GHisAlBERTI AND P. E. HARTMANN \\ Department of Biochemistry, University of Western Australia, Nedlands, \\ Western Australia, 6009, Australia
}

(Received 28 May 1980 - Accepted 3 September 1980)

\begin{abstract}
1. Milk productions and $7 \mathrm{~d}$ dietary records were determined on twenty-seven mothers who had been breast-feeding for $1,3,6,9,12$ or 15 months.

2. The mean milk productions for each group of mothers was $1 \cdot 187,1 \cdot 238,1 \cdot 128,0.884,0.880$ and $0.951 \mathrm{~kg} / 24 \mathrm{~h}$ at $1,3,6,9,12$ and 15 months of lactation respectively. There was no significant difference between two milk determinations 3-7d apart on each mother or between the mean milk production of each group of mothers.

3. Energy intakes of the infants was found to be higher than the usually-accepted values at 1 and 3 months of age but by 6 months were similar to the accepted normal values.

4. Energy intakes of the mothers although greater than those recommended for similar non-lactating women were not sufficient to take into account the energy content of the milk.
\end{abstract}

Recent reviews on human lactation have commented on the lack of information on milk production from well-nourished mothers and concluded that this information is required for the assessment of infant nutrition in both developed and underdeveloped countries (Jelliffe \& Jelliffe, 1978 $a, b$; Whitehead et al. 1978). Following studies by Wallgren (1945) and Lönnerdal et al. (1976) in Sweden and a number of studies in underdeveloped countries (see review by Jelliffe \& Jelliffe, 1978 a), it is currently held that maximal milk productions are $700-900 \mathrm{ml} / 24 \mathrm{~h}$ and that breast-feeding alone can be nutritionally adequate for only the first 3-6 months of an infant's life (Thomson \& Black, 1975; Jelliffe \& Jelliffe 1978 a, b; Waterlow \& Thomson, 1979).

There has been a resurgence of breast-feeding by Australian mothers during the past decade (Simbert, 1975) and many of these mothers now breast-feed into the infant's second year of life (Shade, 1980). We have studied milk productions of two mothers in Perth who adequately breast-fed their infants fully for more than 12 months (Rattigan et al. 1979). The values we observed $(1.51$ and $2.15 \mathrm{~kg} / 24 \mathrm{~h})$ indicated that the milk production of the Perth mothers was markedly higher than elsewhere and suggested that a wider cross-section of mothers should be investigated. (Preliminary communication of these results were given in Rattigan et al. 1979). This paper reports milk productions for twenty-seven normal Perth mothers studied at 1-15 months of lactation and discusses the nutritional implications of their lactation to their infants and themselves.

EXPERIMENTAL

Mothers volunteered for the study and were selected solely on the basis of the duration of their lactation and that the mothers were breast-feeding on demand. A total of twenty-seven mothers were divided into six groups, three groups with five mothers each at 1,3 and 6 months of lactation, and another three groups with four mothers each at 9, 12 and 15 months of lactation. Details of the mothers are given in Table 1. The mothers were defined either as fully breast-feeding if the infant was receiving no other food or drink apart from water, or partially breast-feeding if their infant was receiving other foods. The mothers were either members of the Nursing Mothers' Association of Australia or acquaintances of the researchers. 
Table 1. Details of mothers studied

\begin{tabular}{|c|c|c|c|c|c|c|c|}
\hline $\begin{array}{l}\text { Length of } \\
\text { lactation } \\
\text { (months) }\end{array}$ & $\begin{array}{c}\text { Age } \\
\text { (years) }\end{array}$ & $\begin{array}{c}\text { Weight } \\
\text { (kg) }\end{array}$ & $\begin{array}{l}\text { Height } \\
\text { (m) }\end{array}$ & Parity & $\begin{array}{l}\text { Sex of } \\
\text { child } \\
\text { studied }\end{array}$ & $\begin{array}{c}\text { Member } \\
\text { of } \\
\text { NMAA }\end{array}$ & $\begin{array}{l}\text { Breast } \\
\text { feeding }\end{array}$ \\
\hline 1 & 34 & 70 & 1.64 & 3 & $q$ & Yes & $\mathrm{F}$ \\
\hline i & 39 & 68 & 1.64 & I & q & No & $\mathrm{F}$ \\
\hline 1 & 28 & 67 & 1.70 & 3 & $0^{t}$ & Yes & F \\
\hline 1 & 34 & 49 & 1.54 & 3 & 3 & Yes & $\mathrm{F}$ \\
\hline 1 & 33 & 53 & 1.49 & 3 & $0^{*}$ & No & F \\
\hline 3 & 34 & 65 & 1.68 & 3 & $\vec{a}$ & No & $\mathbf{F}$ \\
\hline 3 & 31 & 68 & 1.63 & 1 & $q$ & Yes & $\mathrm{F}$ \\
\hline 3 & 28 & 48 & 1.60 & 2 & a & No & $\mathbf{F}$ \\
\hline 3 & 31 & 51 & 1.57 & 2 & $q$ & No & $F$ \\
\hline 3 & 33 & 62 & 1.66 & 2 & q & Yes & $\mathrm{F}$ \\
\hline 6 & 30 & 60 & 1.65 & 3 & 0 & Yes & $\mathbf{P}$ \\
\hline 6 & 23 & 57 & 1.52 & 2 & 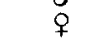 & Yes & $\mathrm{F}$ \\
\hline 6 & 34 & 54 & 1.66 & 4 & $\sigma^{+}$ & Yes & $\mathrm{F}$ \\
\hline 6 & 38 & 56 & 1.68 & 2 & $\sigma^{*}$ & Yes & $\mathbf{P}$ \\
\hline 6 & 28 & 52 & 1.51 & 2 & $q$ & Yes & $\mathbf{P}$ \\
\hline 9 & 25 & 45 & 1.55 & 3 & $q$ & Yes & $\mathbf{P}$ \\
\hline 9 & 33 & 66 & 1.71 & 2 & $q$ & Yes & P \\
\hline 9 & 24 & 56 & 1.60 & 3 & q & Yes & $\mathbf{F}$ \\
\hline 9 & 26 & 56 & 1.70 & 2 & $\sigma^{*}$ & Yes & $\mathbf{P}$ \\
\hline 12 & 30 & 53 & 1.52 & 3 & 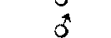 & Yes & P \\
\hline 12 & 29 & 52 & 1.63 & 1 & 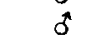 & No & P \\
\hline 12 & 32 & 54 & 1.63 & 3 & q & Yes & $P$ \\
\hline 12 & 36 & 54 & 1.64 & 4 & $0^{*}$ & Yes & $P$ \\
\hline 15 & 31 & 49 & 1.65 & 2 & a & No & $\mathbf{P}$ \\
\hline 15 & 30 & 65 & 1.69 & 1 & ధ & Yes & $\mathbf{P}$ \\
\hline 15 & 32 & 53 & 1.64 & 2 & $q$ & No & $P$ \\
\hline 15 & 28 & 54 & 1.63 & 1 & $0^{+}$ & Yes & $\mathrm{F}$ \\
\hline
\end{tabular}

F, full; P, partial.

Each mother was studied for a $7 \mathrm{~d}$ period, which included two measurements of their milk production 3-7 d apart, and a $7 \mathrm{~d}$ dietary record for the others made by noting all food and drink which was consumed in measured portions (Pekkarinen, 1970). Dietary records for the infants were made on the $2 \mathrm{~d}$ that their mothers' milk production was determined. Milk production of the mothers was measured by a test weighing procedure. The mother's weight was recorded before and after breast-feeding with a beam balance (Avery Australia Limited, type 3550-AAA balance). The accuracy and precision of this method was assessed by measuring the increase in body-weight following consumption of a known weight of fluid. With an average intake of $178 \mathrm{~g} \pm 69$ (mean $\pm \mathrm{SD}$ ) the mean difference between the estimated and known intake was $1.0 \mathrm{~g}$ with an SD of the difference of $10.0 \mathrm{~g}$. The mothers were trained in the use of the balance by measuring the increase in their body-weight following consumption of a known weight of fluid. The production of all breast feeds given within $24 \mathrm{~h}$ from the time of the initial breast feed was measured. Energy intakes of the mothers and infants were calculated from the dietary records with reference to Thomas \& Corden (1970) and milk production measurements assuming the energy content of human milk to be $2 \cdot 9 \mathrm{MJ} / 1(700 \mathrm{kcal} / \mathrm{l})$. 
RESULTS

The results of the milk productions measured for each mother are given in Table 2. Milk production for fully breast-feeding mothers ranged between 0.680 and $1.637 \mathrm{~kg} / 24 \mathrm{~h}$ with a mean of $1.212 \mathrm{~kg} / 24 \mathrm{~h}$. The milk production for partially breast-feeding mothers ranged between 0.43 and $1.397 \mathrm{~kg} / 24 \mathrm{~h}$ with a mean of $0.871 \mathrm{~kg} / 24 \mathrm{~h}$. The mean $( \pm \mathrm{sE})$ milk production of the primiparous mothers was $1.225 \pm 0.147 \mathrm{~kg} / 24 \mathrm{~h}$ and of the multiparous mothers was $1.023 \pm 0.066 \mathrm{~kg} / 24 \mathrm{~h}$.

A two-way analysis of variance showed that there was no significant difference between either the two milk production estimates for each mother or the milk productions observed at $1,3,6,9,12$ or 15 months of lactation. There was no significant correlation between either milk production and the birth weight of the infant or between milk production and the weight of the infant at the time of study. A significant correlation $(r 0.413, P<0.05)$ was found between feeding frequency, expressed as no. of feeds $/ 24 \mathrm{~h}$ and milk production. The mean feeding frequency was 5.9 feeds $/ 24 \mathrm{~h}$ with a range of three-twelve feeds $/ 24 \mathrm{~h}$. There was a significant difference $(P<0.001)$ between milk productions recorded from fully-and partially-breast-feeding mothers but no significant differences between milk production from primiparous and multiparous mothers.

\section{Infant growth}

The infants' weights at the time of the study are given in Fig. 1. Also given are the 10th and 90th percentiles of weight for combined male and female Australian children from Charts and Tables of Heights, Masses and Head Circumferences of Infants and Children (NH \& MRC 1975). The mean \pm SE birth weight for the infants was $3.54 \pm 0.07 \mathrm{~kg}$ and all the infants had satisfactory weight gains from birth to the time of study. There was no significant difference between fully-breast-fed infants and partially-breast-fed infants in weight gain since birth to the time of study.

\section{Energy intakes}

Infant. The energy intakes for the infants calculated from their milk intake and from the 7-d dietary records are given in Fig. 2. The energy intakes for the fully-breast-fed infants ranged from a maximum at 1 month of $0.975 \mathrm{MJ} / \mathrm{kg}$ per $24 \mathrm{~h}$ to a minimum at 9 months of $0.273 \mathrm{MJ} / \mathrm{kg}$ per $24 \mathrm{~h}$ with a mean intake of $0.591 \mathrm{MJ} / \mathrm{kg}$ per $24 \mathrm{~h}$. The total energy intakes of partially-breast-fed infants ranged from 0.572 to $0.338 \mathrm{MJ} / \mathrm{kg}$ per $24 \mathrm{~h}$ with a mean of $0.446 \mathrm{MJ} / \mathrm{kg}$ per $24 \mathrm{~h}$ for infants from 6 to 15 months of age. The energy intakes of partially-breast-fed infants due to foods other than breast milk ranged from 0.034 to $0.317 \mathrm{MJ} / \mathrm{kg}$ per $24 \mathrm{~h}$.

A one way analysis of variance and least significant difference analysis (Snedecor \& Cochran, 1978) showed that the energy intake at 1 month of age was significantly greater $(P<0.05)$ than at any other month. Also energy intake was significantly greater $(P<0.05)$ at 3 months than at either 9 or 15 months. There was no significant difference between other ages.

Mother. The energy intake of the mothers calculated from the 7-d dietary records are given in Table 3. Also given are the recommended energy intakes for non-lactating women of the same age and weight from reference to the Dietary Allowances for Australian Women (NH \& MRC 1971). The energy intakes minus the loss of energy in the milk are also shown.

The actual intake, recommended intake and energy intake minus the energy loss in milk are all significantly different $(P<0.05)$. The mother's actual energy intake was greater than the recommended energy intake for non-lactating women with a mean difference of $1.34 \mathrm{MJ} / 24 \mathrm{~h}$. However, the energy intake minus the energy loss in milk was less than the recommended intake for non-lactating women with a mean difference of $1.77 \mathrm{MJ} / 24 \mathrm{~h}$. 


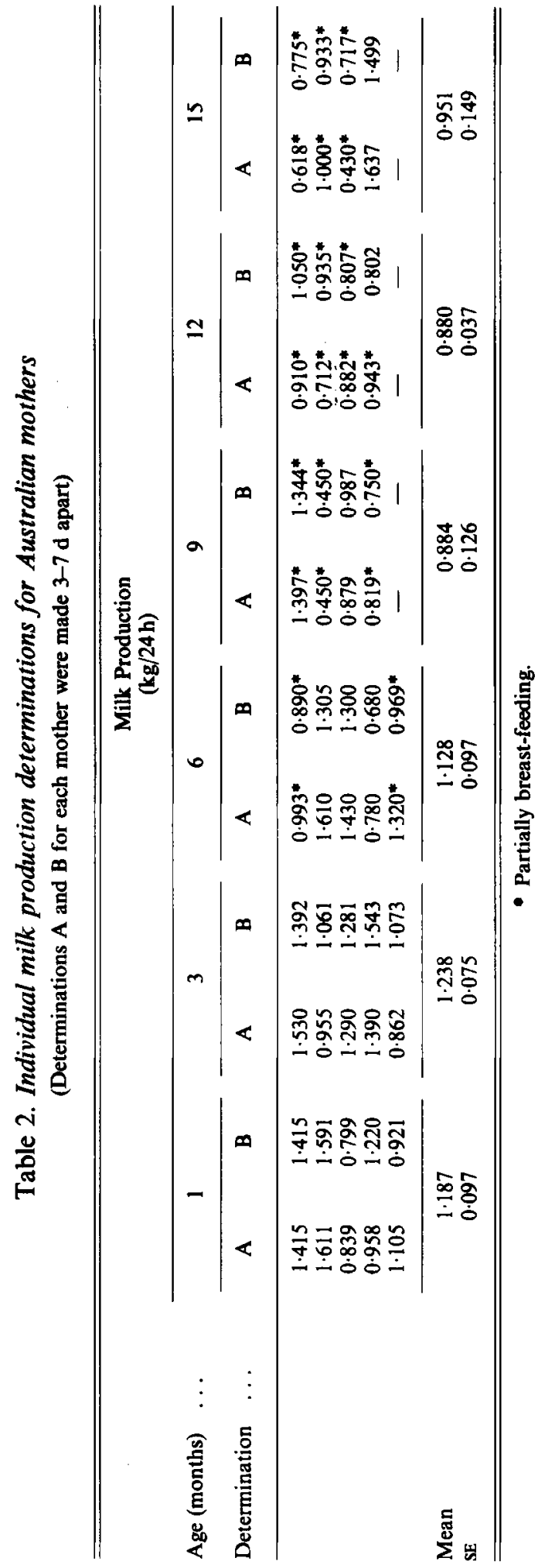




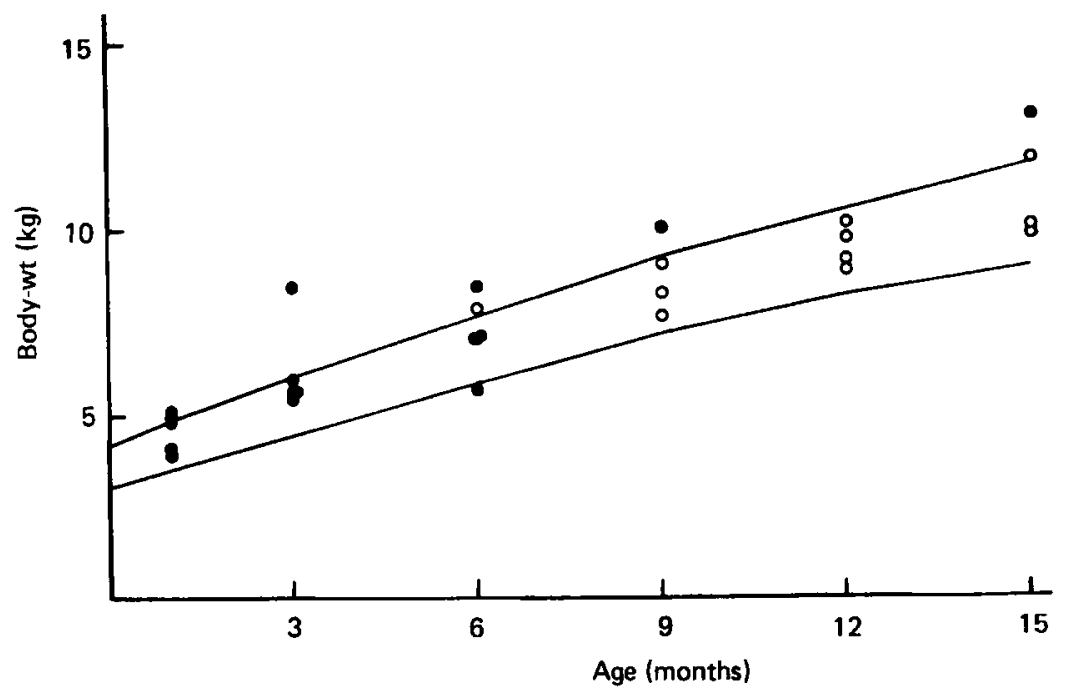

Fig. 1. The body-weights (kg) of infants of Australian mothers at the time the milk productions were determined. (O), Fully-breast-fed; $(O)$, partially-breast-fed infants. The lower and upper curves represent the 10 th and 90 th weight percentiles for Australian infants (NH \& MRC, 1975).

Table 3. Mean energy intakes, energy intake minus the energy loss in milk and recommended intakes $(M J / 24 h)$ for similar non-lactating women for groups of Australian mothers

\begin{tabular}{|c|c|c|c|c|}
\hline $\begin{array}{l}\text { Length of } \\
\text { lactation } \\
\text { (months) }\end{array}$ & & $\begin{array}{l}\text { Actual } \\
\text { intake }\end{array}$ & $\begin{array}{l}\text { Energy-Energy } \\
\text { intake in milk }\end{array}$ & $\begin{array}{l}\text { Recommended } \\
\text { intake }\end{array}$ \\
\hline \multirow[t]{5}{*}{ I } & $\begin{array}{l}\text { Mean } \\
\text { SE }\end{array}$ & $\begin{array}{l}9.26 \\
0.73\end{array}$ & $\begin{array}{l}5.78 \\
0.65\end{array}$ & $\begin{array}{l}8.76 \\
0.45\end{array}$ \\
\hline & Mean & $\begin{array}{r}0.73 \\
10.73\end{array}$ & $\begin{array}{l}0.65 \\
7 \cdot 10\end{array}$ & $\begin{array}{l}0.45 \\
8.50\end{array}$ \\
\hline & SE & $\begin{array}{r}1.24 \\
1.24\end{array}$ & $\begin{array}{l}1.09 \\
1.09\end{array}$ & $\begin{array}{l}0.40 \\
0.42\end{array}$ \\
\hline & Mean & 9.06 & 5.75 & $8 \cdot 19$ \\
\hline & & 0.66 & 0.38 & $0 \cdot 14$ \\
\hline \multirow[t]{2}{*}{9} & Mean & 8.75 & $6 \cdot 15$ & $8 \cdot 20$ \\
\hline & & $1 \cdot 11$ & $1 \cdot 30$ & 0.43 \\
\hline \multirow[t]{2}{*}{12} & Mean & $9 \cdot 26$ & 6.68 & 7.94 \\
\hline & SE & 1.67 & 1.61 & 0.06 \\
\hline \multirow[t]{2}{*}{15} & Mean & $10 \cdot 81$ & 8.02 & $8 \cdot 15$ \\
\hline & $\mathbf{S E}$ & $0 \cdot 28$ & 0.72 & 0.37 \\
\hline Mean & & 9.65 & 6.54 & 8.31 \\
\hline SE & & 0.41 & 0.40 & 0.14 \\
\hline
\end{tabular}

\section{DISCUSSION}

Breast-feeding in Australia has increased since 1971 and this increase is closely associated with the growth of the Nursing Mothers' Association of Australia (NMAA) (Simbert, 1975; Hartmann et al. 1980). Two-thirds of the mothers in our study are members of the NMAA (Table 1). In Perth $83.4 \%$ and 76.9\% of babies are fully-breast-fed at 6 weeks and 3 months of age and at 6 months, $4.3 \%$ of babies are fully-breast-fed and $60 \%$ of babies receive on average $80 \%$ of their energy intake from breast milk (Hitchcock \& Owles, 1980). Taken in this context the mothers (Table 1) are not atypical of the breast-feeding mothers in Perth. 


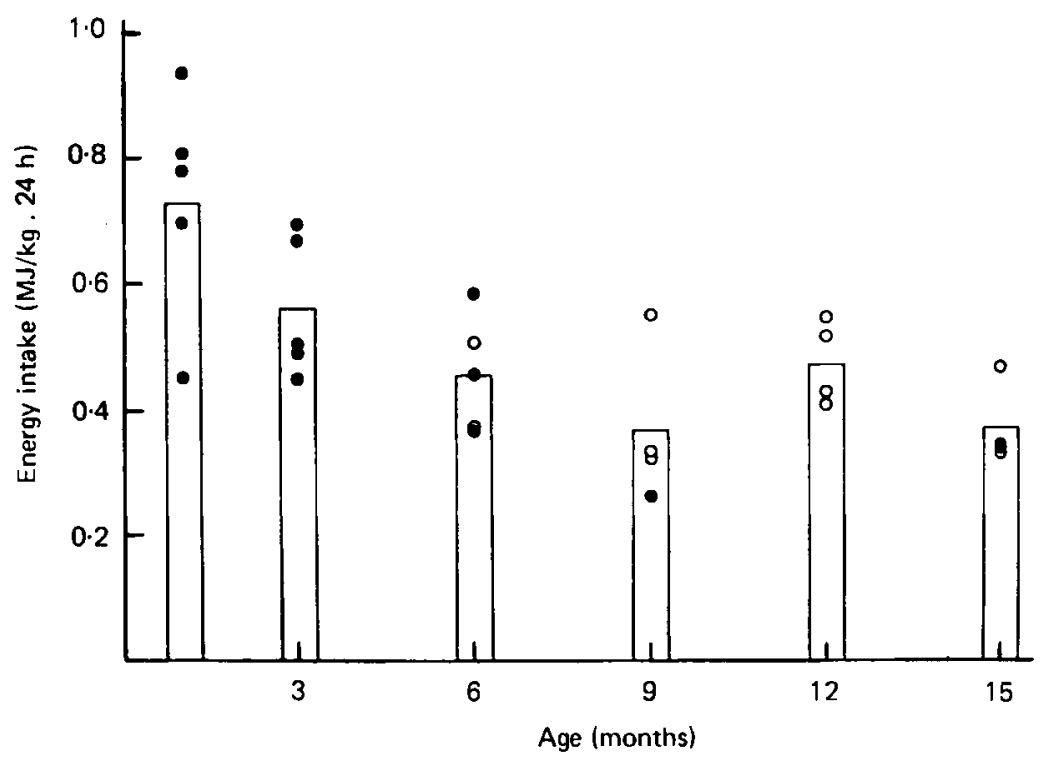

Fig. 2. The energy intakes (MJ/kg per $24 \mathrm{~h}$ ) for infants of Australian mothers. ( $\square$ ), Mean energy intake for each group of infants; (O), fully-breast-fed; $(O)$, partially-breast-fed.

No significant difference was observed between milk production values determined 3-7d apart on each mother, indicating that the values are representative of each mother and that milk production does not fluctuate greatly from day to day. The milk production values reported in this study (Table 2) are greater than those reported by either Wallgren (1945) or Lönnerdal et al. (1976), the most commonly quoted for well-nourished mothers (Jelliffe \& Jelliffe, 1978 $a, b$; Waterlow \& Thomson, 1979). These higher levels of milk production (Table 2) are consistent with the growth patterns of the infants (Fig. 1). Twelve of the fifteen fully-breast-fed infants had body-weights above the 50th percentile for Australian children (Fig. 1). Also the growth of fully-breast-fed infants was satisfactory even up to 15 months of age, a situation which would not be possible if the milk productions had been lower (Jelliffe \& Jelliffe 1978 a). In addition, a prospective study of nutrition and growth of Perth infants by Hitchock \& Owles (1980) has found that, in Perth, the average body-weight of fully-breast-fed infants is significantly higher than that for bottle-fed infants of both 6 weeks and 3 months of age.

The reason(s) why milk production in Perth mothers is higher than elsewhere are not easily elucidated. Egli et al. (1961) and Applebaum (1970) report that milk production is related to feeding frequency in humans. In the present study and our previous observations of two mothers during weaning (Rattigan et al. 1979), we have observed a significant correlation between milk production and feeding frequency. Perth mothers feed their infants according to the infants' needs (Hitchcock \& Owles, 1980). Therefore, milk production in Perth mothers may be in part controlled by feeding frequency. In this connection, Australian mothers are recommended to increase feeding frequency if they wish to increase their milk production (Phillips, 1976).

The energy intake (per unit body-weight) for the infants was calculated assuming the energy content of breast milk to be $2 \cdot 9 \mathrm{MJ} / 1(700 \mathrm{kcal} / \mathrm{l})$ (Jelliffe \& Jelliffe $1978 b)$. This energy value must be considered arbitrary because of the large variations in the concentration of milk fat from the beginning to the end of a breast-feed (Hall, 1975). However, the average 
composition of breast milk between 2 and 12 months from Perth mothers is relatively constant (Hartmann \& Kulski, 1978) and therefore we would not have expected the energy content of milk from the mothers in this study to have varied greatly. On this basis, the high energy intakes we observed for infants at 1 and 3 months (Fig. 2) are very different from accepted values (Fomon, 1974) and suggest that it is necessary to reassess our understanding of the energy requirements of breast-fed infants.

The energy intake of the mothers (Table 3 ) although greater than recommended values for similar non-lactating women, are not great enough to account for the loss of energy in the milk. Even though no account is made for the energy cost of milk production to the mothers, the intakes when corrected for the loss of energy in the breast milk brings many of these mothers to near their basal energy requirements. Gopalan \& Belavady (1961) observed similar findings in Indian mothers and it has been suggested by these authors and by Rajalakshmi (1971) that there are profound alterations in metabolism during lactation and therefore our findings for energy intakes of well-nourished mothers support their suggestion.

The authors thank the Nursing Mothers' Association of Australia for their co-operation, Allan Borushek for advice on collection of dietary information and Helen Nottage for the preparation of the figures. This research was supported by a grant from the TVW Telethon Foundation.

\section{REFERENCES}

Applebaum, R. M. (1970). Pediat. Clin. N. Am. 17, 203.

Egli, G. E., Egli, N. S. \& Newton, M. (1961). Paediatrics, Springfield 27, 314.

Fomon, S. J. (1974). Infant Nutrition. Philadelphia: W. B. Saunders Co.

Gopalan, C. \& Belavady, B. (1961). Fedn Proc. Fedn Am. Socs. exp. Biol. 20, 177.

Hall, B. (1975). Lancet i, 779.

Hartmann, P. E. \& Kulski, J. K. (1978). J. Physiol., Lond. 275, 1.

Hartmann, P. E., Kulski, J. K., Rattigan, S. \& Saint, L. (1980). Proc. Nutr. Soc. Aust. 5, 104.

Hitchcock, N. E. \& Owles, E. (1980). Proc. Nutr. Soc. Aust. 5, 71.

Jelliffe, D. B. \& Jelliffe, E. F. P. (1978a). Am. J. clin. Nutr. 31, 492.

Jelliffe, D. B. \& Jelliffe, E. F. P. (1978b). Human Milk in the Modern World. London: Oxford University Press.

Lönnerdal, B., Forsun, E. \& Hambraeus, L. (1976). Am. J. clin. Nutr. 29, 1127.

NH \& MRC (1971). Dietary Allowances for use in Australia. Canberra: Australian Government Publishing Service.

NH \& MRC (1975). Charts and Tables of Heights, Masses and Head Circumferences of Infants and Children.

Canberra: Australian Government Publishing Service.

Pekkarinen, M. (1970). Wld Rev. Nutr. Diet. 12, 145.

Phillips, V. (1976). Successful Breast-feeding, p. 131. Australia: Nursing Mothers' Association of Australia.

Rajalakshmi, R. (1971). Trop. Geogr. Med. 23, 117.

Rattigan, S., Ghisalberti, A. V. \& Hartmann, P. E. (1979). Proc. Nutr. Soc. Aust. 4, 115.

Shade, E. (1980). NMAA Newsletter 16, 3.

Simbert, J. (1975). Med. J. Aust. 2, 954.

Snedecor, G. W. \& Cochran, W. G. (1978). Statistical Methods, 6th edition. Iowa: lowa State University Press.

Thomas, S. \& Corden, M. (1970). Tables of Composition of Australian Foods. Canberra: Australian Government

Publishing Service.

Thomson, A. M. \& Black A. E. (1975). Bull. Wld Hlth Org. 52, 163.

Wallgren, A. (1945). Acta Paediat. 32, 778.

Waterlow, J. C. \& Thomson, A. M. (1979). Lancet ii, 238.

Whitehead, R. G., Rowland, M. G. M., Hutton, M., Prentice, A. M., Müller, E. \& Paul, A. (1978). Lancet ii, 178. 